Ferguson, John.

Book of secrets.

AG

103

F4 


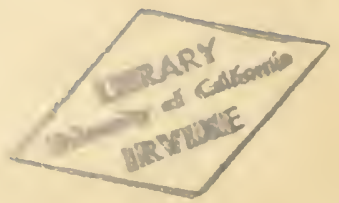




\section{UNIVERSITY OF CALIFORNIA LIBRARY, IRYINE}

\section{BOOKS OF SECRETS.}

A PAPER READ BEFORE THE BIBLIOGRAPHICAL SOCIETY, APRIL 2I, I9I3.

BY

PROFESSOR FERGUSON.

LONDON :

REPRINTED BY BLADES, EAST \& BLADES, FROM THE SOCIETY'S TRANSACTIONS.

$$
\text { I9I4. }
$$



BOOKS OF SECRETS. 



\section{BOOKS OF SECRETS.}

A PAPER READ BEFORE THE BIBLIOGRAPHICAL SOCIETY, APRIL 2I, 19I3.

BY

PROFESSOR FERGUSON.

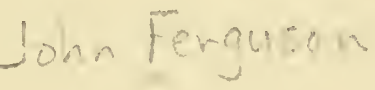

LONDON :

REPRINTED BY BLADES, EAST \& BLADES, FROM THE SOCIETY'S TRANSACTIONS.

I914. 


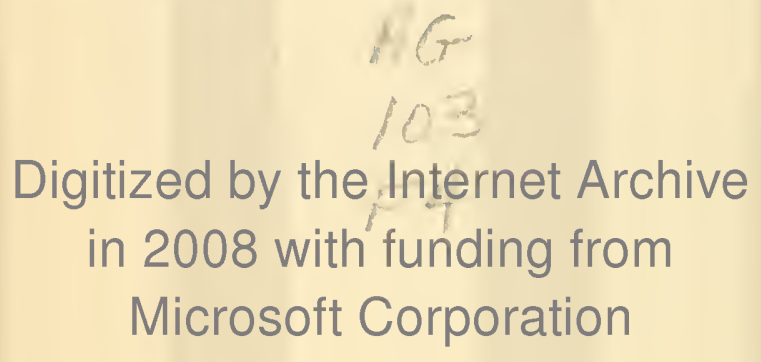

http://www.archive.org/details/booksofsecretspa00ferg 


\title{
BOOKS OF SECRETS.
}

\author{
BY PROFESSOR FERGUSON.
}

Read April 2rst, 1913.

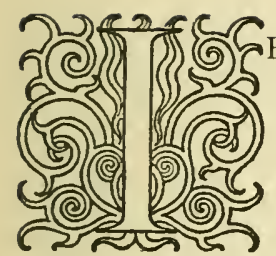

this theme had not, in a manner, been prescribed to me by our Secretary, I myself should hardly have selected it for presentation to the Society. It is true that I have been rummaging among these books for a good many years past, from time to time have printed some results, and ought to be able to say something about them, but I am so far from having exhausted the material which has gathered, that I am hardly prepared as yet to pass a judgment on this branch-historical, I may remind you-of scientific, or rather technological, literature. I repeat technological, for the aim of the greater part of it is not to speculate, or discuss, or describe, but to give directions how to do something, how to produce something tangible, a practical result for human use or convenience. Hence "secrets," as they are called, have, from this point of view, no reference to religious, or philosophical, or masonic, or other mysteries, but simply denote "receipts," which are used even now for effecting certain purposes.

It is unnecessary to dwell on the name. We may, however, deduce from it, that, at one time or other, the artist or craftsman had special knowledge gained by practice and experience which was personal and which he, intentionally or unintentionally, kept to himself. This accumulated skill constituted the "secrets" of his art or craft, and whoever 
wished to acquire these "secrets" had to serve an apprenticeship to the master, and be initiated by him. That it was personal one can comprehend, for when the productions of different men, with the same material and with the same processes for the same ends are compared, the difference in the results is sufficiently marked. 'The work of Peter Vischer, for example, or of Benvenuto Cellini, or of Bernard Palissy, stands out conspicuously among that of their contemporaries, to go no farther, through their "secret," or personal skill and knowledge.

Even after the processes had been published and the "secrets" divulged, it did not follow by any means that anyone, still less everyone, could carry out the directions accurately, not to speak of the results achieved by their authors. Something more is wanted than the written or spoken word, for as Opie showed long ago the brains and conscience of the artist are not negligible components of success.

By degrees, presumably, the "secrets" oozed out and were disseminated among the craftsmen and were finally collected and published. They retained their distinctive name, however, for though now displayed to common view, they had been "secrets" once and might bear that title still.

My acquaintance with these books began when I was engaged with a different subject, and I was disposed at first to resent their intrusion, but as their numbers increased and the use made of them in the past became more obvious by the variety of topics dealt with and the number of editions, they acquired a practical importance and a bibliographical interest, not to say significance, and I drifted into the examination of them, without anticipating in what it might ultimately involve me. That, however, is the usual course of research and one of its charms, and I have yielded to it. So starting with a score or two of treatises and editions, I have been led on to an examination and recording of books of which previously I had no knowledge, and which, so far as I know, have never been brought together and catalogued before. After all, the number of them which have passed through my hands is but a small one, a couple 
of thousand at the outside, and even that number would have been reduced, had I adhered to my original intention. I certainly began the survey, over thirty years ago, with an attempted restriction of the lists to books specifically labelled "secrets." But it was almost immediately apparent that the limitation was artificial and impossible to enforce, that consideration of the mere title must be discarded and the inquiry based on the broader foundation of the theme. So from the very first were included books of receipts in general, even though not designated "secrets."

From these, however, have been deliberately omitted books on gardening, cookery, occult science, and old chemistry. ${ }^{1}$ These truly are all books of receipts and are replete with secrets, but they have been often dealt with and I have had no desire to compete with the lists already published, when there are extensive subjects for investigation to which no attention has been paid.

Again, while there are many books of receipts which are not styled "secrets," there are also books of "secrets" which contain no receipts. These have been included in virtue of their name rather than of their contents, it may be thought unduly. They profess to reveal some obscure or unknown matter which does not necessarily entail any practical application or result. The term is especially applied to natural phenomena, Natural History as it might be called now, but then, the secrets, wonders or marvels of Nature. The contemplation of these marvels was very like what it is with the ordinary man now. The daily routine of Nature passes without remark; no one, for instance, is conscious of what Father Beccaria called "the mild and slow electricity which prevails in the atmosphere during serene weather," but when anything out of the common happens, a tempest, a flood, a snowstorm, an earthquake, thunder and lightning,

(I) Nevertheless circumslances have again been too strong for me, and have compelled me to admit some books on these topics, because they were in the company of others which fell within my prescribed area, or were written by authors of whose works it was an object of mine to make as complete an cnumeration as possible. 
that is at once talked about. So in the earlier times the unusual events were noticed, but defective observation and partial ignorance of their causes coupled with superstitious fears, led to their being credited with sinister significance, and being assigned to malign agencies.

Books of Secrets, therefore, are of diverse sorts, and I have not hesitated about including all the varieties attainable. But just on that account the theme is so extensive and can be contemplated from so many points of view that it is impossible to include them all within a single paper. Attention, consequently, may be restricted to one or two aspects. One, for example, which concerns the Society more particularly, deals with the characteristics of the books themselves; another with their contents, but I shall not attempt to keep these separate. As books they are in all languages, they are of all dates, sizes, and qualities of paper, printing and binding, and they are in every kind of condition, good, bad and indifferent. There are the books which were in everybody's hands, and those which can never have been used at all. In such cases it is not always easy to see what was the merit which carried a book through many editions, when others, seemingly as good, if not better, were quite unsuccessful. That, however, is not now a topic for discussion.

Prior to the sixteenth century there is little in printed form that can be brought into the category of Books of Secrets. The encyclopædias which remain, notably those of Isidorus, of Bartholomæus de Glanvilla and Vincentius Bellovacensis, even though they glance at practical matters, are too comprehensive to be included under such a limited designation. But that collections of technical receipts were in use is shown by the work of Theophilus, which was known only in manuscript till it was printed in French in 1843 , and afterwards in English in 1847 . This work contains receipts for colours, glass, enamel and metal work. Other manuscripts on colours, painting, glass and other arts of the Middle Ages were published by Mrs. Merrifield in 1849 , and the work on colours by Heraclius was edited in 1873 by Albert Ilg, who also began an edition of Theophilus the next year. 
But the outstanding book of Secrets of the earlier time is that ascribed to Albertus Magnus and, curiously enough, it was the first book of the kind which came into my possession. That copy is a quaint little volume, printed at Lyons in 1566, and it contains the three tracts, Secreta Mulierum, Liber Aggregationis, and De Mirabilibus Mundi. The popularity of these tracts down to the eighteenth century is extraordinary. Hain enumerates forty-six editions before 1500 , and there are some which have escaped his notice, such as those printed in London by Machlinia, and an Italian translation of the Liber Aggregationis at Milan in 1495. Many followed in the sixteenth and seventeenth centuries, so that as dealing with the secrets of generation, the properties of stones, plants and animals, and the marvels of the universe, no book had such a circulation in Furope. Whoever has given any attention to medieval literature must have encountered it at some time or other.

Intimately connected with it by subject, and often by publication, was the analogous work De Physiognomia of the senior contemporary of Albertus, Michael Scotus, round whom so much romance has been woven, but a consideration of that book would involve a monograph so as to do it and its author justice.

After 1500 books on the present subject made their appearance in greater abundance. Notable rarities are among them and many printed in the earlier part of the sixteenth century are not devoid of bibliographical attractions. Among those in English are many on medicine, such as the editions of "The Treasure of pore men," "The Myrrour or Glasse of helth," "The treasury of healthe," written by Petrus Hispanus, afterwards Pope John XXI, and translated by Humfre Lloyde. There were the works edited or translated by John Hester, "The Joyfull Jewell," "Secrets of Chirurgery," "The Excellence of Physick and Chirurgery," "Three curious Pieces of Secrets," "The Order to distill oyles," "The Key of Philosophie"; Baker's "The Newe Jewell of Health"; Vicary's "Englishman's Treasure"; "An Hospital for the Diseased"; "A Rich Store-house or Treasury for the Diseased"; 
"Prepositas his Practice" by Leonard Mascall, and others. There was no lack of guides to health, if it could be attained or preserved by secrets and receipts.

Mascall wrote other books on practical affairs such as the planting and grafting of trees, "The Booke of Cattell" concerning the management of live stock, horses, oxen, sheep, goats, hogs, "The Governmente of Poultrie," probably the earliest treatise on the subject in English, "A profitable Boke to take out spottes and staines," which is one of a set of books to which reference is made below. To these may be added the works on gardening by 'Thomas Hill, his "Parfite orderinge of Bees," his "Physiognomy," and other works. Another little tract similar to some of these is "The Booke of Thrift, containing a perfite order, ... to profite lands, and other things belonging to Husbandry," printed at London by John Wolfe, in 1589 .

In the seventeenth century the output of these books was greater than ever. Occasionally they were respectable small quarto volumes, while those in small octavo were for the most part chap-books. But though cheaply got up they were sometimes decorated, if one may say so, with a woodcut portrait or title-page, or frontispiece. Among the quartos may be mentioned the late reprints of Hill's and Mascall's books on gardening, on cattle and arboriculture, and Gervase Markham's works on farming, and household economy. In this century too appeared Hill's "Legerdemain," which ran through so many editions that one might suppose the art of conjuring was a much cultivated profession. Works on the secrets of medicine were not wanting; Brugis' "Marrow of Physic," Levens' "Pathway to Health," Bonham's "Chyrurgian's Closet," the "Dispensatory" of the two quacks, Salvator Winter and Francisco Dickinson, and reprints of earlier treatises nay serve as examples.

Of the little octavos and duodecimos which flowed from the press in a copious stream, mention can be made of only a few that are more or less typical. There were the works of John White, "lover of artificial 
conclusions," as he styled himself, "Arts Masterpiece," "Arts Treasury of Rarities and curious Inventions," which went through six editions at least, "A rich Cabinet with variety of Inventions," which was in vogue from $\mathrm{x} 65 \mathrm{I}$ to $\mathrm{r} 689$, and "Hocus-Pocus," another book of tricks. There were : "A choice Manual of rare and select Secrets in Physick and Chyrurgery" by Elizabeth Talbot, Countess of Kent, which, between I 653 and 1708 went through twenty-one editions; the parallel collection of Queen Henrietta Maria, entitled "The Queen's Closet opened," with about sixteen editions between 1655 and $\mathrm{I}_{7} \mathrm{I} 3$, and a certain $\mathrm{T}$. P. who compiled "The Accomplished Lady's Delight in Preserving, Physick, Beautifying and Cookery" which ran from 1672 or 1673 to 1719 , and had ten editions. Salmon's "Polygraphice," a collection of receipts for a number of Arts, was issued eight times between 1672 and I701. Besides these, reference may be made to Mrs. Hannah Wolley, or Woolley, an entertaining person, and an adept in all feminine accomplishments, who was the authoress of "The Cooks Guide," "The Gentlewomans Companion," "The Ladies Delight, or a Rich Closet of Choice Experiments and Curiosities," "The Ladies Directory," "The Queen-like Closet," of whicl there were certainly five editions, all these books appearing between 1664 and 1684 . Nor should Sir Kenelm Digby be forgotten, and his operator George Hartman, who between them published "Chymical Secrets," "The Closet opened," "Choice and experimented Receipts in Physick and Chyrurgery." There was also the revelation of a thorough-going secret in his famous "Discourse on the Powder of Sympathy," delivered at Montpellier and first printed in English in 1658 , a book said to be of the greatest rarity. The second edition appeared in the same year, others came later and, with other books of Digby's, it was translated into Dutch, French and German. Hartman compiled "A Choice Collection of rare Secrets and Experiments," "The true Preserver and Restorer of Health," "The Family Physitian, . . containing some hundreds of considerable Receipts and Secrets of great Value" which was printed by Henry Hills in 1696 , and from which we gather that the author 
lived at Rotherhithe. There was Owen Wood's "An Alphabetical Book of Physicall Secrets," of which five editions appeared between $163^{2}$ and I656, when it was issued under the name of the Duchess of Lenox. This book has caused me trouble, for Owen Wood has never got credit for his labour, such as it was.

A representative book of Secrets is that by Thomas Lupton, " $A$ thousand notable things of sundry sorts," which was published in London in 1596 and was often reprinted, the last issue I know of being dated I 8 I 5 ! What was the secret, or receipt, to which this book owed its longevity, does not appear, but one would like to know it. It cannot be owing to its intrinsic merit, for the book is a rifacimento of the extravagancies of the old marvel-mongers.

Towards the close of the century a good many of the books of Secrets were published by G. Conyers at the Ring in Little Britain, but with the unpardonable omission of the datc. Other publishers were John Starkey, Edward Brewster, N. Boddington, T. Salusbury, T. Sowle, Andrew Sowle, T. Passenger, W. Whitwood, N. Crouch, Gartrude Dawson, E. Tracy, Charles Tyus, J. Blare, and many others. Among the chap-books were "The way to save Wealth," attributed to Thomas Tryon, the author of several curious essays, who in some of his ideas was far ahead of his time, "The Complete Husbandman," "A New Book of Knowledge" full of curious information and actually with a date, 1697. There were also more receipt books for ladies, such as John Shirley's "Accomplished Ladies Rich Closet of Rarities," which enjoyed some popularity, "'The Ladies Companion, or Modern Secrets and Curiosities, never before made Publick" concerned mainly with toilet secrets, "The Accomplished Female Instructor," dated I704, and "Arts Compleat Master-Piece," containing receipts for all sorts of purposes, and sold by James Hodges at the Looking-glass on London Bridge.

On passing into the eighteenth century one encounters books different in style and to some extent different in theme. Collections of medical 
secrets almost disappear, but there are more on strictly practical subjects. The term "secrets" is dropped, though it may occur in the course of a title. But the titles now become of prodigious length and take the form of a table of contents. They may have been handy for the readers of a hundred and fifty or two hundred years ago, but they try the patience of the bibliographer of the present time, who has to copy them. As might be expected too the books are not attractive. There is a pretence at ornament which is not only unnecessary, but is ugly.

There was a second flood of manuals of legerdemain, with the name of H. Dean. At first the books were well enough, but as time went on the issues became so bad that some were illegible.

Directions for the ladies and the good wives were supplied in such works as "The whole Duty of a Woman," "The complete Housewife," which, more by merit than looks, managed to reach the fifteenth edition, "The Complete Family Piece," which, in a duodecimo of six hundred pages, with an overwhelming title-page for length and detail, gives a history of the active side of country life in England a hundred and seventy years ago, and "The Lady's Companion, or an infallible Guide to the Female Sex." "The Young Ladies School of Arts" dealt with the refinements rather than the necessities of daily life and is the converse of "The Farmers Wife or the complete Country Housewife." This last contains directions about poultry, about the preparing of pork, bacon and sausages, making wine, cyder, perry, mum, mead, and so on, directions for the dairy, etc., etc., and then the author blossoms into rhyme, like Mascall in his book on cattle:

Instructions full and plain we give

To teach the Farmer's wife

With satisfaction how to live

The happy country life.

There were other books on the fine arts: "The Handmaid to the Arts" is mostly about painting; "Valuable Secrets concerning Arts and Trades" is also largely about painting though other topics are included. There are at least half a dozen editions of this book. "The School of IVisdom" contains a survey of the arts in general. All these books have ponderous title-pages 
and are disagreeable examples of typography. There are more of the same kind. "The Fountain of Knowledge or Complete Family Guide," which begins with the Indian way of marking silk, linen or woollen, tells how to breed game-cocks and singing birds, to restore an apparently drowned person to life, gives rules for nursing, a cure for the small pox and a receipt to remove freckles. This pamphlet is by "Sarah Saunders, Mother of serenteen Children, and brought them through all Diseases incident to Children "; an excellent mother but weak in syntax. I have seen the first edition, besides the sixth, which is in the British Museum. Amongst other things it contains a description of the "expeditious or fountain pen," which is, therefore, an old invention.

There were also "The New Handmaid to the Arts," "The School of Arts," and "The Laboratory or School of Arts," this last adapted from the German.

In the first quarter or so of the last century books after the old fashion still appeared, as, for example, "The Painters and Varnishers Guide," I 804, from the French; the seventh edition in 1810 of "The Laboratory," just mentioned ; "The Female Instructor," on manners, medicine, cookery and domestic economy; "The Family Receipt-book," undated, a quarto of six hundred pages in double columns, with an appalling title-page; "500 Useful and amusing Experiments in the Arts and Manufactures," by George G. Cary. Books on fireworks, on conjuring, on the toilet, are among the receipt books of the time.

All these and many more are of such a quality that interest in them falls to a minimum, whether as regards their contents or their execution.

When, leaving chronology, we cxamine the contents of the books, they appear to be about as varied as human wants and desires themselves, and to be ready to provide efficient practical guidance for most of the contingencies of every day life. A brief notice of a few of the subjects may be given.

The section of the literature which deals with the Secrets of Nature is a remarkable one, for in it we see the method of descriptive Natural History 
in its widest aspect, previous to the introduction of the more recent system of observation and experiment. 'To the ordinary man the world is full of marvels and secrets which he does not understand and of forces which he cannot always control. These phenomena in the course of time were observed, sometimes accurately, and interpreted in many ways, not always conclusively. The familiar authorities from classical times are, of course, Aristotle, Theophrastus, Dioscorides, Pliny, Seneca and others. For the medieval writers, Pliny was the chief guide, but all sources were drawn upon by those who compiled, for popular delectation, narratives of strange appearances and events. Such were the "Liber Aggregationis" of Albertus Magnus, already alluded to, and in the sixteenth century the "Prodigies" of Polydore Vergil and of Julius Obsequens, the "Histoires Prodigieuses" of Boaistuau, the "Occulta Naturæ Miracula" of Levinus Lemnius of Zierikzee, Johnson's "Cornucopix," and the "Secrets and Wonders of the World abstracted out of Pliny" in English in 1587 .

At the same time Arthur Golding translated Solinus and Pomponius Mela, both of whose histories arc storehouses of marvels. There wcre the "Contemplation of Mysteries" compiled by Thomas Hill and printed by Denham about $157 \mathrm{r}$, and the natural history of John Maplet of Cambridge, called "A greene Forest," published in 1567 . As early as ${ }_{1563}$, Dr. William Fulke, the controversialist and divine, wrote a book about meteors. What is called the second edition appeared at London long after in $6_{34}$ in a little black letter volume entitled "A most pleasant Prospect into the Garden of Naturall Contemplation." It is divided into five sections and describes meteors, ficry meteors, ayry impressions, watry impressions, such as clouds, rain, snow, springs, lakes, rivers, the sea, and carthly meteors, such as metals and stones. Hill's book resembles Fulke's sufficiently to make it worth while comparing them.

A century later, alsout 1670 , came the popular manuals with the initials R.B., or the name R. Burton, published by Nath. Crouch and indeed assigned to Crouch himself as the author. 
The self-assigned task of all the writers was to record astonishing and unusual events, signs and wonders in the heavens above and in the earth and sea below, portents, the birth and prophesyings of monsters, and such like. The writers did not seek to verify their reports, or, if they ran counter to ordinary experience and observation, to criticize them, but set them down for what they were worth, to be accepted or rejected. Such collections, if we may judge by their number and variety, were popular and must have supplied what was required, strange and startling narratives, true or not did not matter, just as one accepts an impossible romance now for the passive excitement it affords.

One of the most singular of these collections is in French and it appeared in I $5^{\circ} 4$, entitled "Le livre des Merveilles du Monde," the book of the wonders of the world. It went through some six or seven editions which search for many years has shown me are of rare occurrence. It is divided into two parts; the first is arranged by the countries of the old world, and the wonders of each are enumerated, the second deals with the wonders of beasts, birds, plants, stones, and man, and is arranged by subject. The compiler has withheld his name unfortunately, so he cannot get credit and commendation for his production, but he has been wise and considerate enough to mention his authorities for the marvels he has amassed, so that we can judge of their probability and authenticity and confirm them if so disposed. Solinus's "Polyhistor" is one of his main sources, but, on the whole, the most attractive stories are derived from the collection which Gervasius, called of Tilbury, made for the recreation and edification of the Emperor Otto IV, a book of which there is no proper edition. One can imagine how the Emperor, when he was off duty (the work is entitled "Otia Imperialia," "an Emperor's half holiday") would recline luxuriously and purr while Gervasius tickled the imperial ears with his amazing narratives. It is no exaggeration to call them so, for even the compiler is forced to say about some of them that they "are hard for a man like myself of uncultivated understanding to believe, for in truth without the honour of the deeply learned doctor Gervasius the marvels 
seem to me impossible to believe according to nature, for Aristotle relates nothing like them. But it may well be that those to whom these marvellous events happened, were cheated by some diabolical illusions or otherwise."

One feels disposed to agree with the compiler and to say of Gervasius what King James VI said of the witches of Tranent, that "they were all extream lyars," though the editor here rather spoils his Higher Criticism by quoting Aristotle and the devil. But "otherwise" is good; it is such a roomy alternative.

In this book the stories are told at some length, but in others they are reduced to the smallest dimensions and only the essential part is preserved. Such is the treatment of the subject in Thomas Johnson's "Cornucopiæ," a thin black letter pamphlet of 24 leaves, printed at London in 1596 , and in the translation of Pierre de Changy's abstract of Pliny, printed at London in 1587 . As it contains only thirty-six leaves in small 4to, the barest outline of Pliny's thirty-seven books in folio is the result, but the wonders have been culled with due attention to their exceptional character.

Of equal interest and curiosity is the collection of Pierre Boaistuau, which was put out in English as an original work by Edward Fenton in r569. It too contains remarkable stories and it possesses an unusual feature in the form of woodcuts illustrating different narratives. These do ample justice to the text, and are highly creditable to the imagination of the artist. The author describes monstrous men and animals, but what he says would not be intelligible without the pictures. People were much exercised in those times about the origin of monsters, and small wonder considering the appearance of those depicted and described. There was always a doubt too about the share devils had in producing them, and whether in general devils could have families. Then there are accounts of natural wonders: great floods, burning mountains, including the eruption in which Pliny perished, with a woodcut of the catastrophe; 
marvellous appearances in the heavens, comets, dragons, flames, blazing stars, torches, fire forks, pillours, lances, bucklers, two suns and two moons at one instant, and many more, "which whosoever would recompte by order, those which onely have appeared sithens the nativitic of Jesus Christ, together, searching the causes of their beginnings and births, the life of a man would not performe the same," and then the author gives details of some of these portents with their dates and their significations. Some of them must have been frightsome enough, if they at all corresponded to their description and picture. The secrets and wonders of Nature in the sixteenth century were calculated to inspire far more widespread interest and alarm than they do now, for by following the prescription of Albertus Magnus, we have lost the capacity for wonder.

Mizaldus, in the sixteenth century, was a successful collector of natural secrets. He read extensively and noted the wonderful things he met with about the world, about beasts, birds, fishes and reptiles, about men and women, children born and unborn, about the virtues of plants and minerals and the cure of diseases. His collections he arranged in nine centuries, with a rough sort of classification. His book is not common and the Cologne editions of $1572,1573,1574$, are of rarity. A more curious and uncommon book by him is entitled "Secrets de la Lune," in which he points out its connection with and influence upon the sun, women, certain beasts, birds, fishes, stones, trees, plants, diseases, sick people, etc., etc.

Founded upon Mizaldus's book and taken in part from it, is Lupton's book already alluded to: "A Thousand notable things of Sundry Sorts."

Bodin and Cardan made contributions to this literature, and there may be quoted two much less known works than theirs.

One is "Idea del Giardino del Mondo" by Thomaso Thomai of Ravenna. It was published at Venice in $\mathrm{I} 593$ and often afterwards. Notwithstanding its small bulk it is comprehensive; begins with the earth, deals with all its products, animal, vegetable and mineral; with men, 
women, monsters; with the preservation of health; with the air, the winds, and aerial demons, comets and other alarming signs in the heavens, thunder and lightning, the rainbow ; with fire, animals that live in it, and fiery demons ; the seven planets, the signs of the zodiac, and the crystalline sky. His authorities are classical for the most part, but he has got interesting material from some later writers, mostly Italian.

The other is entitled "Jardin de Flores Curiosas," by Antonio de Torquemada. The earliest edition seems to be that published at Salamanca in 1570 , and it was printed several times thereafter. It was turned into French by the well known Gabriel de Chappuys under the title Hexameron, at Paris, 1582 ; into Italian by Celio Malespina, Giardino di Fiori Curiosi, Vinegia, I591 ; into English under the curious title The Spanish Mandevile of Miracles, London, 1600, and again in 1618, and into German, Hexameron, oder Sechs Tage-Zeiten, Cassel, 1652.

It gets the name Hexameron from its being the report of a six days' conversation on the wonders and secrets of Nature and the topics discussed are recondite and almost incredible.

On the first day the discourses are appropriately inaugurated by stories about strange and abnormal births, monsters, satyrs, pigmies, giants, amazons, tailed men, dog-headed men, tall men, strong men, mermaids, mermen, long livers, people who have renewed their youth, others who have changed their sex, centaurs and such like.

The second conversation turns upon rivers, fountains and lakes, and the unexpected properties which some of these display, and the discussion naturally includes the four rivers of Paradise and its locality, the flood, and winds up with some account of idolatry and heresies of various sorts.

The third discourse is about visions, enchanters, witchcraft, and contains matter which the author himself calls delightful and necessary to be known. It is, quite. 
The fourth conversation is somewhat discursive, treats of good and bad fortune, of the influences of the heavenly bodies and of many singular occurrences.

The fifth conversation is about the lands near and around the North Pole, the variation in the length of the day and night, the inhabitants, the climate, and similar details.

The last discussion is about the animals that live in the Northern - regions, wolves, hares which become white when snow begins, trees that remain green all the year and other curiosities.

The whole book is an excellent summary. I hope here be truths.

While these writers are mere compilers of strange stories about Nature, others endeavoured to treat Natural History from a common sense point of view. They could not free themselves altogether from the marvellous, but they tried to keep that element within bounds and to give rational descriptions.

One of them was Joannes Jonstonus, who wrote a review of the subject under these heads: the heavens, the four elements, meteors, fossils (mineral substances), plants, birds, quadrupeds, bloodless animals (insects), fishes, man. The classification is a cross one, lizards, for instance, are put among quadrupeds, but the attempt at a classification at all, based upon observation of characters, represents a marked advance, and indicates that the old kind of Natural History was passing away.

Other books that may be noticed in this connection are Robert Lovel's "Panbotanologia," and "Panzooryctologia," the former a treatise on British plants, the latter on animals and minerals. They contain much information, not very critically sifted, with a view specially to pharmacy and therapeutics. Though of little service in that way now, they are not to be despised in connection with the history of medicine and more particularly of medical folk-lore, a branch of the subject of which the significance and value are now fully recognised by historians in Germany. 
Lovel's aggregations may serve as a transition to those on medicine itself, with its related and ancillary sciences. They are in all languages, of all degrees of merit, and treat of different sections of the subject. Leaving out the medical authorities of the Middle Ages, Galen and Avicenna, and the protagonists of the revolution of the sixteenth century, Paracelsus and Erastus, with their respective followers and disciples, attention must be confined to the books written for popular use, many of which went by the name of secrets. They were not systematic but practical; their aim was to cure, not to theorize or expound ; and the remedies given were as straightforward and simple as possible. They therefore took the form of receipts, which dictated to the patient, or nurse, the drugs to be used, or the course of treatment to be followed, or the diet most suitable, without troubling him about the origin or nature of the disorder. The author probably thought that the patient had trouble enough with the disease itself, and his drugs, without adding knowledge of the cause of it, always supposing that he knew it himself, which was doubtful. In these times, so far as one can gather, the practice of medicine by licensed persons with such training as could be had, was restricted to populous centres, but in country districts few physicians or surgeons were available, and, from what is stated here and there, when they were, they charged large, if not prohibitive fees. So it came about that the treatment of disease had to be managed by each household for itself. As the men were occupied otherwise, it fell almost inevitably into the hands of the women to attend to the health of the children, as well as their own, and to that of the men folks who might be ill or have met with an accident. The necessary knowledge they had to acquire as best they could by experience and trial and from the skill of their elder neighbours. It was for their use largely that the books of medical receipts were compiled and they were often dedicated to ladies and gentlewomen distinguished by their care of the sick, and especially of the sick poor round about them, who could obtain no medical advice or attention. A survival of these times was the manual of our grandmothers and great-grandmothers, Buchan's "Domestic Medicine." 
The ladies and housewives had not only the nursing to do, but they had to prepare the medicines also, and as by tradition these were almost exclusively vegetable, it followed that in every garden were cultivated faniliar medicinal herbs, which were supplemented by others that grew naturally in the woods and ficlds, by the roadsides and ditches.

This gave rise to another branch of medical literature, the pharmaceutical, and one of its earliest forms was the "herbal," of which there - were many varieties, and which in recent years have afforded much sport to collectors, and especially to booksellers.

As a consequence, part of the equipment of a house of any size was a "still" room, in which were prepared the spirits, oils, extracts, cordials, perfumes, essences and medicines in common use. The products were more or less secret and were kept in a special room, the "Closet" as it seems to have been called, access to which the lady reserved to herself, perhaps because some of her preparations were too active-shall we say?-to fall into either ignorant or too skilful hands, or because some of the preparations were scarce, or costly, or of her own invention, and she had no mind to disclose them. They were her "Secrets," in fact.

These developments were not without their influence upon the literature, not merely of medicine, but of connected subjects. As illustrations of the herbal for popular use may be cited that ascribed to Aemilius Macer, though it is not the work of Virgil's predecessor or elder contemporary, but is of a later period. It was translated into English and published by Banckes in 1525 , then in 1526 , and by several others immediately afterwards. There were Jerome Brunswick's "Vertuose boke of Distyllacyon of the waters of all maner of Herbes," printed by Lawrence Andrewe at London in 1527 ; the "Treasure" of Evonymus, published in $155^{2}$ in Iatin, translated into English and published by Day about 1559 , with plates of the plants and distilling apparatus. It was one of the most popular of the books and appeared in various editions in Latin and in translations in French, German and Italian. The bibliography which I have investigated is interesting. 
After the herbals came books on gardening, and, in at least some of them, attention is bestowed on the cultivation of medicinal plants. There is space for only one example. Thomas Hill, Londoner, of whose life nothing definite is known, not even the dates of his birth and death, in addition to a number of other works already referred to, wrote one entitled "The Profitable Arte of Gardening," 1568. In it he not only lays down rules for planting and tending the flowers, vegetables and herbes, but to each appends a paragraph headed "The physicke helpes," that is, its use in medicine. In "The Gardeners Labyrinth" by Didymus Mountain, commonly identified with Thomas Hill, though the accuracy of so doing may be doubted, there are similar sections in the second part of the book where the individual plants are described. The point to be noticed, however, is that in these and similar books there is an overlapping of the subjects of gardening, pharmacy and medicine.

There is still another connection which displayed itself in a marked way in the manuals written by ladies, or under their name. In them, as in the Countess of Kent's “Manual," or in "The Queen's Closet opened," or in "The Queen-like Closet" of Mrs. Wolley, Physicke and Chyrurgerie came to be associated with Conserving and Preserving, and ultimately with Cookery. Such collections appeared frequently, and their popularity is exhibited by those just mentioned having passed through many editions, as has been exhibited above.

Of more interest, perhaps, than some of these books, may be those about the mysteries of reproduction. Here again we meet with works which have been long current, such as the Secreta Mulierum of Albertus, and the Physionomia of Michael Scotus. But a book much better known now than either of these passes under the name of The Complete Masterpiece and is ascribed to Aristotle. Such books were the instructors of people in all that pertained to the subject, theoretical and practical, and one has heard occasionally views expressed the source of which could be found in them. That is not surprising, for the "Masterpiece" has been "Printed 
for the Booksellers" and in popular circulation for over two hundred years. In fact, the book along with other tracts of similar tenour can be purchased in the year of grace 1913 in shops which deal in a certain class of literature. One of the other tracts, also ascribed to Aristotle, is known as the "Problemata." It was printed as early as 147 , went through several cditions before $\mathrm{I} 500$ and ever so many after. It is a sort of catechism of the secrets of the human body and questions are asked to which no reasonable answer could be given, nor would it matter whether they could be answered or not. A supplement, or sort of commentary upon it, was written by Alexander Aphrodisiensis and another by Zimara, and as affording insight into the most recondite secrets of nature, secreta secretorum, all these works must have been much esteemed.

Later writers seem to have adopted its method and copied its matter, for similar productions of equal imbecility appeared in the seventeenth century, such as that by Scipion Dupleix and his translator Robert Bassett.

Here then is the natural history of at least four hundred and fifty years ago-but it must be far more since the compilation was made-current in the year 1913 , with hardly a change of word or notion, as if our knowledge of the Universe had been stagnant all that time; and the rest of the book, though it has undergone considerable alteration, is equally unsatisfactory. The ramifications of the bibliography of this book are not without interest, but this is not the time for such divagations.

It is difficult to get away from books of medical secrets and it must suffice to mention those of Falloppio, the discoverer of the organs which bear his name, Valescus of Taranta, Varignana, author of the "Philonium," Fioravanti, a quack it may be, but a man of strong individuality, several of whose works were translated into English by John Hester, Riverius, Zapata, Bairo, Venturini, Auda, and ever so many more. There are two authors, however, that may be noticed in passing.

One is an undiscoverable person called Raoul du Mont Verd, whose name is attached to a little book called "Les Fleurs et Secrets de 
Médecine," dating from early in the sixteenth century. Brunet enumerates a number of editions; there are some-not in Brunet-in the British Museum ; I have one or two in neither, so we may infer that there were a good many issues, that it must have been in demand, and that, as the surviving copies demonstrate, the book got hard usage.

It gives directions how and when to bleed, an art almost forgotten; how to manage sick people in the months of the year; how to treat various diseases; it describes the virtues of certain plants and how to make waters from them, and gives numerous medical receipts. This is followed by an astrology for shepherds, a treatise on comets and their significance according to the signs of the zodiac in which they appear, a section on the magnitude of the Universe, and the book concludes with a description of hell, deep down in the earth, dark, cloudy, redolent of sulphur and other bad smells and enveloped in nine kinds of fire.

This is a real book of secrets, but its origin is obscure. It is said to be compiled by Master Raoul du Mont Verd; translated from Latin into French, the which book Hippocrates sent to Jalius, who was ill of various maladies external and internal. In another place, however, it is said that the book was sent by "Hippocrates to Galen, ... and that the contained receipts were afterwards approved by Galen." These statements are hard to reconcile, and one would gladly know how Hippocrates bridged the gap of some five hundred years between himself and Galen.

The other book is also of the sixteeenth century and is "The Myrrour or Glasse of helth," usually ascribed to Thomas Moulton. It is a little black letter octavo and deals especially with the plague, the causes of it, how to avoid it, and how to treat one who is attacked by it. Then follow the influences of the planets in the days of the week, and the signs of the zodiac in the months of the year from March to February, and remedies "for dyvers Infyrmytes and dyseases, that hurteth the bodye of man." It has some analogy therefore to the preceding volume. 
The history of this book is curious, for it appeared in two distinct forms and with different title-pages. Examination of the two raises doubts about 'Thomas Moulton, of whom nothing is recorded, so far as I have ascertained, except that he was a I)ominican friar, and was urged to compose this tract. In the other issue part of Moulton's work is omitted and some of the remainder is claimed by one who speaks of having been in medical practice for many years. This subject, however, must be discussed elsewhere, along with the other contemporary medical works quoted above, such as the "Treasure of Pore Men" and the "Treasury of Health."

The books of receipts for arts and manufactures are in great numbers. Some of them are general and contain directions for all kinds of practical purposes, while others take up one topic only but with fuller detail.

Amongst the general collections, there is one of the sixteenth century which is too conspicuous to be passed over. It is that which goes by the name of Alexis, or Alessio, of Piedmont. ${ }^{1}$ It presents problems as to its origin and history, it went through quite a number of editions and translations and in its final form contained a great deal of matter. It was the model which subsequent compilers followed and was a reservoir of information which could be drawn on if required, so that in a way the book is one of the classics of the subject. It is a remarkable gathering, for though it is not devoid of many singular notions, disagreeable remedies, superstitious beliefs, all the more does it throw light on the state of knowledge and skill at the time, the demand there was for information and guidance, and the practical methods which must have been current, and of which, it is likely, only samples found a place in the book.

It first appeared in 1555 , in Italian, and consisted only of the first part or division in six books. A second division followed, possibly by the

(1) Some years ago I discussed the author and the bibliography of the book in a paper read to the Society of Antiquaries, but as the printing of it was postponed and has never been carried out, I am unable to refer to the lists I then drew up. 
same author, and then divisions three and four which, almost certainly, are not by Alexis. They were translated into English at different times and published, the earlier ones separately, and latterly all four together. The English version of the first part appeared in $155^{8}$, and is rare. The last collected edition in English is of 1615 . The authorship is usually assigned with great confidence to Girolamo Ruscelli, and the name Don Alessio is considered a pseudonym. This view, however much it may seem to be confirmed by Ruscelli himself, Sansovino and Muzio, introduces so much contradiction and confusion that one can arrive at no satisfactory result. It is an obscure subject and would take too much time to discuss now, but this question of authorship does not affect the book and its contents.

The First division contains a variety of receipts. The first book furnishes preparations for cure of diseases and healing of sores; the second how to make fragrant and essential oils, perfumes, powders, soaps; next a few receipts for toilet purposes, beautifying the skin, dyeing the hair, preserving the teeth, etc., etc. ; the fifth book shows how to make inks and colours, and the sixth book deals with salts, metals, gilding, precious stones, true and false. The Second division contains such a miscellaneous accumulation of receipts, that it is impossible to classify them. To the Third division are assigned medical, sanitary, and cosmetic secrets, but at the end there is the collection of receipts from the German to which reference is made later on. The Fourth division is occupied entirely with medical receipts and preparations.

As can be easily understood it is difficult either to describe, or to criticize, or to appraise the value of the hundreds of secrets, so called, in such an aggregation as this famous book is. On looking over it one can see that some directions are empirically sound, that drugs employed for certain diseases then, are or could be employed still, and that methods of preparation then, attained the same ends as now, but with an expenditure of time and labour which has been reduced to smaller compass by a fuller understanding both of the materials and of the necessary processes. 
A noticeable feature of these books is the constancy with which the receipts both for medicine and for everyday wants are repeated without alteration in one edition after another. Apparently, the secrets gained in authority by repetition, and if they had stood the test of time and had yielded the expected result, there was no reason why they should be changed or superseded.

As instances of receipt books concerned with one topic only, examples may be selected again from the Italian.

Ōne is upon dyeing, and is entitled: "Plictho, or the art of the dyer, how to dye wool, silk, linnen." It was written by Gioanventura Rosetti and published at Venice in I $_{540}$. It forms a thin small quarto of fortyfour leaves, and contains one or two woodcuts depicting parts of the process. This is a collection of dyers' receipts and methods; it describes the quantity of the substances required, the length of time the fabric is to be immersed in the colour bath and the whole treatment. The art of dyeing is of great antiquity and the use of mordants to make colours fast, for example, must have been known at an early period. Of this book there were at least five editions, the first of 1540 already mentioned, the fourth at Venice in 1611 , and the fifth in 1672 , with some changes and additions, but even with these, one hundred and thirty years is a good life for such a book. Modern technical books are much more short-lived.

When engaged with dyeing one must not overlook receipts for making inks and colours, for taking out spots and stains and for colouring wood, bone, and feathers. These are chemical applications and as such I have described them in a series of papers still in progress. ${ }^{1}$ The earliest collections of these receipts which I have seen are in German and of date I 53I, in following years tracts of similar character were associated with them and translations of them were made. I have seen some fifty editions of these books, but from internal evidence it is probable that that number

(I) Proceedings of the Royal Philosophical Society of Glasgow, from 1888 to 1913. 
does not include all the editions which exist, but which have not yet come to light. Some of the ink and colour receipts taken from these books long survived the originals, for they are to be found repeated verbatim late in the eighteenth century.

Another subject which was the origin of some literature at a later time was miniature painting, specimens of which are now collected with much zeal. One of the most popular was the work ascribed to C. Ballard, "Traité de Mignature," which consists of receipts about colours and their use. It had a wide circulation and was translated into English and Italian.

Another Italian book is the "Pirotechnia" or "Art of Fire," by Vannuccio Piringuccio, a contemporary of Rosetti, for his book was also published at Venice in $154^{\circ}$, and several times thereafter, one edition appearing in 1678 , another instance of a life of over 130 years. It was translated into French and a small part relating to gold and silver was included in Eden's version of Peter Martyr's "Decades of the New World," 1555. This is a comprehensive treatise upon all the arts in which fire, or, as we should say now, high temperatures are necessary. It therefore includes metallurgy, the distillation of sulphur, the making of salts of various kinds, the construction of furnaces, the manufacture of glass, crucibles, and other vessels and apparatus, assaying, casting of cannon, preparation of gunpowder, alloys, metal working, wire-drawing and similar arts. Illustrations of apparatus and processes are included, and altogether it is a book of importance for the history of metallurgy and chemistry.

Along with this may be taken another, even more specialised. In $16 \mathbf{r}_{2}$ Antonio Neri published his book "L'Arte Vitraria." He was in the works at Murano and his book embodied his experience. It was translated into Latin, into French by De Blancourt, into English by Christopher Merrett, who added notes, and into German by Kunckel, who included Merrett's notes as well. Illustrations were added, and it became a sort of text-book. An encyclopædic edition in French, under the editorship of Baron 
d'Holbach, was published at Paris in $175^{2}$, and finally the English version was printed privately at the Middlehill press in a ridiculous folio in I 826 . Therc are modern works on glass by Sauzay, Peligot and others.

Among the older writers, Babington, Nye, Hanzelet, Jones, have given receipts for fireworks, and there are two or three on the same subject in Dutch.

On a totally different subject from dyeing, Gioanventura Rosetti, the author of "Plictho" above mentioned, published a little book in I 555 and again in ${ }^{5} 50$. It is entitled "Notandissimi Secreti de l'arte profumatorio," and in it he gives receipts for preparing oils, waters, pastes, muscardines, and what not, and all for the use of ladies.

This art was a favourite one and it would be easy to cite examples of its literature from the days of Mercurialis, Liébaut, Le Fournier, to Hugh Plat and his "Delights for Ladies," "The French Perfumer," Erresalde (De la Serre), Marinello, Jeamson and his "Artificial Embellishments," and others down to Lola Montez and the present time. It is but a few years since I picked up at the bookstall at Dover Station a new pamphlet on the Secrets of the Toilet for one penny sterling. There have been others since then.

While some of the topics touched upon have been secret enough, the most sombre quarter is occupied by books on magic, and especially black magic. Luridly conspicuous among these is the popular French "Dragon Rouge," and the secrets of Albertus Parvus, Le petit Albert, where one can find how to fabricate the hand of glory which endows its possessor with strange powers. There are the extraordinary revelations contained in the "Magick of Kiranus, King of Persia," and the "Trinum Magicum " of Longinus. The volume on Occult Philosophy by Cornelius Agrippa, which is full of mysteries, is less a treatise on magic than an early attempt to construct a speculative Natural Philosophy, and similar efforts were made by Cardan, Baptista Porta, Athanasius Kircher, Hernando Castrillo, Zimara and others, who styled their subject Magia 
Naturalis. Caspar Schott advanced a step farther, when he called his books "Magia Universalis" and "Physica Curiosa"; in these he gets rid to a great extent of the "secret" element, and deals with physical phenomena pure and simple. The subject, thereafter, developed along two lines, one the scientific, the other the secret or occult, ending practically in legerdemain and conjuring. An instance of transition of another sort was displayed in the case of the graduation thesis of Martius, De Magia Naturali, printed in 1700 , which passed through a number of editions and took the form more or less of a conjuring book. Then it worked gradually into a book of experimental Physics, after which a volume containing an account of all the newest discoveries appeared annually for nineteen years.

Legerdemain, like other displays of manual dexterity, merits respect. Its secret is the cultivation assiduously of certain endowments, physical and mental. Conjuring, involving as it does certain appliances unknown to the spectator, is one of the oldest of arts, for it is said that in the Egyptian temples traces of the arrangements required to produce mysterious effects are still to be found.

Modern conjuring literature, so far as it is known to me, began about I630, or perhaps a little earlier, and has continued at intervals to the present time. The earlier books, as was said above, bore the name of Thomas Hill, ${ }^{1}$ later ones in the eighteenth century that of H. Dean. There was another crop early last century, and John Anderson, the famous "Vizard of the North," published a handbook of Magic about $185^{\circ}$. Quite recently came a set of books called "The Secret out" Series, reviving thereby the old name, and at the present moment hand-books of Parlour Magic can be readily procured, which profess to instruct the aspirant in all the secrets of prestidigitation.

(I) Perhaps as one of the earliest specimens ought to be reckoned the translation which Thomas llill published in 1567 , under the name of "Natural and Artificial Cunclusions," of the fatuous tricks compiled, it is said, by sundry scholars of the University of Padua, much to their discredit. 
The books enumerated above have been for the most part in English, but they form only one section of those which exist. 'They were produced in abundance in Europe generally, in Latin, French, German, Italian, Dutch and other languages, and translations from one language to another were common enough. The same desire for knowledge seems to have prevailed in other countries as in England, and the same methods were adopted to satisfy it. There was no other source free to people anxious for practical instruction and information, there was no technical education, and only in such receipts and directions as could be obtained from the books of "secrets" could people become acquainted with the properties and uses of different substances.

The books are pretty much of the same character everywhere, though they do not cover exactly the same ground. 'Thus in English medical secrets predominate, while in other languages the collections are more general. Italy, especially, was prolific in books of the kind and excelled in the issue of small pamphlets of from four or eight to twelve or sixteen pages, with florid titles and a little kernel of secrets of varied content. Of these evanescent productions I have seen about thirty, but that must be a fraction of those which have been in circulation. It is noteworthy that the deterioration in the externals of the volumes is as patent in the books produced on the Continent as here, showing that general causes were at work, while in the matter of long-winded title-pages and crude ornament the books of the eighteenth century were the same everywhere.

In a review of these books during four centuries and a half, successive styles of book production cannot escape notice. Those of the sixteenth century are in black letter and are generally pleasing and sometimes even handsome, though some by Wyer and others are not creditable to the printer. For the majority of those produced in the seventeenth century little that is favourable can be said; the execution of the books gradually deteriorated until, towards the end of that period, printing had fallen to the lowest ebb. The books, even the best of them, are of inferior quality. The paper is coarse, the printing rude, and the cover is a bit of brown 
sheepskin, the boards that it is stretched over being left unlined. No attempt was made to turn them out in an attractive shape. They were not written by scholars for scholars, but were meant for common use and were got up as economically as possible. With the exception of Albertus Magnus and Aristotle and may be one or two others, there is not a single author known outside the present connection. Thomas Hill, John Hester, John White, Hannah Wolley, John Shirley, Robert Lovel, Edward Fenton, Owen Wood, A. T., G. W., C. B., who were they? Little or nothing is known about them. Their names are attached in Catalogues to one or more books, and some of them may have found their way into the Dictionary of National Biography, but their names have not borne their books into fame, any more than the fame of their books has perpetuated their names.

But whatever the exterior may have been the contents seem to have been sufficient, and the books served their day and generation. How hard the service must have been is eloquently, if not pathetically, proclaimed by the few victims that have survived, and appeal to us for sympathy. When it is remembered that the circulation must have been enormous, that there was a market for every book of the kind written, that of the popular books edition after edition followed at three or four years' interval, and when after years on years of waiting not a single copy of some of these editions ever appears, one can realise the consumption and destruction that must have gone on and can understand how these books are now so scarce. Sometimes one has the luck to light on a volume of Secrets as fresh as if it had just come from the Looking-glass on London Bridge, or from the Ring, or the Pelican in Little-Britain, or from Ducklane, but that is a phenomenal exception. For one cannot go into the market and purchase whatever book one wants, and in the condition one would prefer. Some might be acquired without much delay, but for others one might have to wait a life-time. So there is nothing for it but to watch, and when the desired object comes along to seize it. It may be imperfect, it may be dirty, it may be in tatters, but it will be time enough 
to think of that when another copy is found which satisfies our fastidious taste. Besides, another copy may never appear, and that which was secured may be the sole survivor of the edition. Moreover, supposing there be another copy, instead of being in better state than that which was despised and allowed to slip, it may be in worse; the lesson whereof is, let no opportunity pass.

When such rarities occur, a copy in unusually fine condition, a hitherto unknown treatise or edition, it is customary to acclaim it as unique, but that is an epithet which should be taken with a lot of salt, for when once the hunt is up it is surprising how other copies come to light and infringe the monopoly. Still, among the books of Secrets there are a few which are provisionally unique. The pursuit and acquisition of such specimens afford some temporary amusement and gratification to the collector.

Research on this subject seemed at first simple, for all that had to be done was to find the books and describe them. But, as has been shown above and as anyone can prove who tries, the finding of the books involves a tedious waiting on protracted time. There is besides the question of cost, which is one of the most significant changes of these latter days. There has been a steady advance in the price of the books as a whole, and a preposterous rise in the case of some, such as gardening and cookery. A raw curiosity is pursuing the old books, and as their number is small and that of their hunters is growing the value of available copies has been correspondingly enhanced. So it happens now that books which were plentiful enough a generation or two ago when nobody cared for them have disappeared from the market and cannot be got at all.

The description of them too is at first easy, and then as usual up spring hydra-headed difficulties which are not despatched at one stroke. There are doubts about authors, doubts about first and other editions. There are different editions in the same year, not impossible with a speedy sale; there is the same edition in different years, or in different size and form in the same year. There are doubts about readings, doubts about 
meanings, doubts, grave doubts, about the veracity and trustworthiness of editors, doubts about almost everything except the bare facts of paper, printing and binding. These troubles are inherent in the books themselves and in the motives of the publishers. Their aim was to push their wares. It was not likely that the bibliographical minutiæ which give the books a fictitious, or adventitious, value in our eyes, ever entered the head oflet us say-Nicholas Boddington, or of his chapmen, still less of the goodwives with whom they chaffered, or that they bothered about whether the editions were numbered or dated or not, which would have been so useful to us now.

Thus the problems instead of being direct and obvious are often crooked and refractory and from sheer want of data the solution must be relegated to a better informed time. Perhaps the solution could be found at once if it were only seen that the data are lying unrecognised and unheeded at our hand. "All difficulties are but easy when they are known."

The subject is not finished, but it is time to stop. From these random selections it can be seen that it is a big one, even when limited. In one aspect it is of no importance, and yet it attracts attention. "Secrets" of course are always alluring, and the promise of a revelation of the hidden meaning will draw many to listen. But the secrets these books disclose are all done with long ago, and are not used for their purpose any more. They can, however, serve another purpose. In short, the books are historical documents and give insight into the knowledge and skill of the times when they were composed. They throw light on the practical life, as the literature illuminates the mental life of those days. From them we can acquire notions of the beliefs and practice of the times and can compare what the books tell us with what remains of the products. For the study of the history of arts and manufactures these books are indispensable, for however inaccurate or mistaken from our point of view the authors may have been, at least the substances they employed were the same as ours, and it is possible thereby to check their statements and 
detect where their knowledge was less extensive than ours and their theories proportionally defective. These are the simultaneous stages of error and amending progress in human conprehension of the outer world and its multitudinous possibilities. Such too exist in our own epoch, and it may be that our successors a couple of hundred years hence, or perhaps in less time, will recognise more clearly than we, who are among the eddies, can do, what a transitory stage it was, if ever they think about it at all. "Let time shape, and there an end."

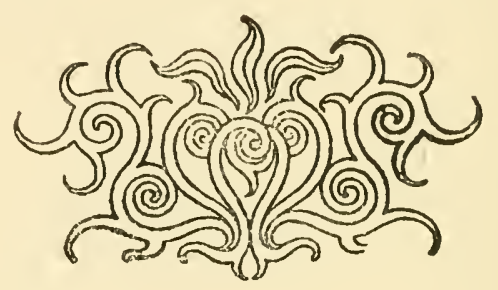






\section{DATE DUE}

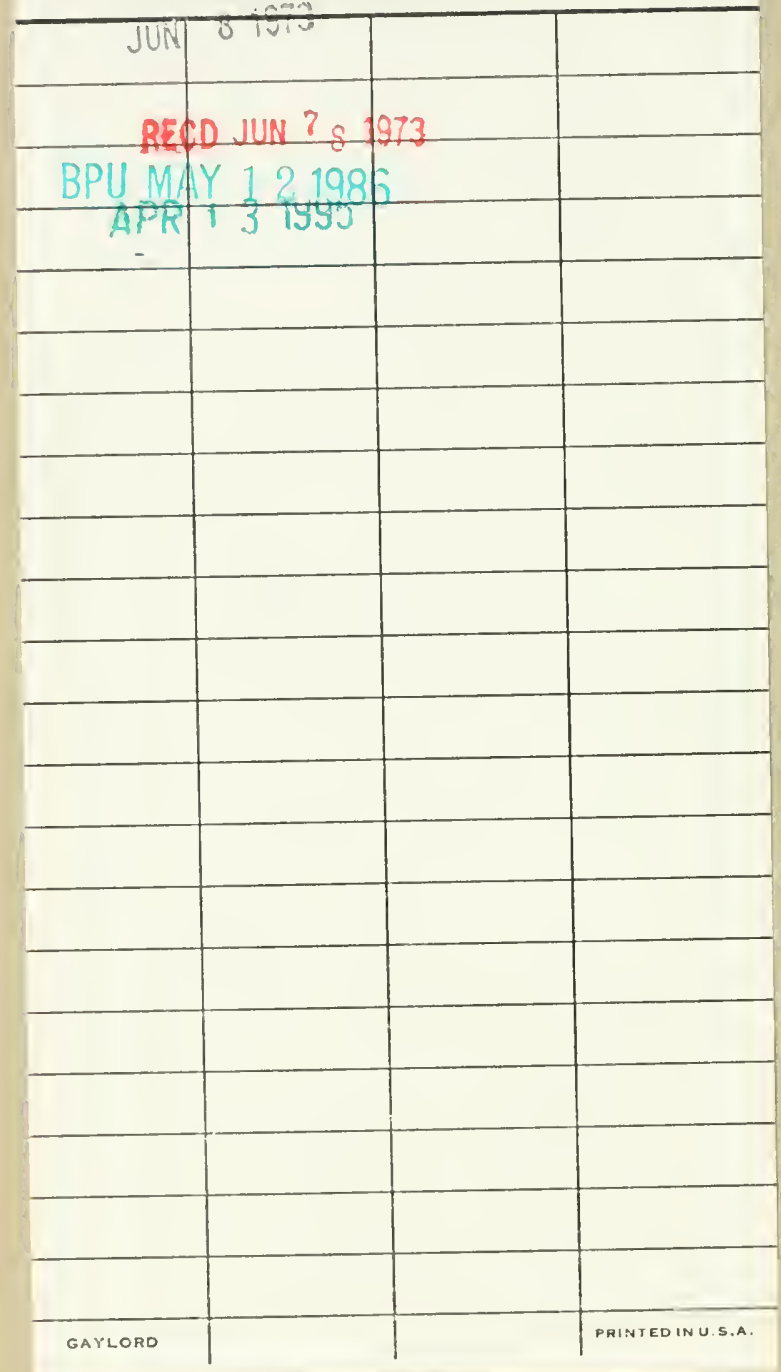


UC SOUTHERN REGIONAL LIBRARY FACILITY 年 
